\title{
Pelatihan Teknik Budidaya Mencit Putih (Mus musculus L.) sebagai Peluang Usaha Kreatif kepada Siswa SMAN 5 Bukittinggi
}

\author{
Putra Santoso, Resti Rahayu, dan Robby Jannatan \\ Fakultas Matematika dan Ilmu Pengetahuan Alam, Universitas Andalas, Kampus Limau Manis, Padang, 25163. Indonesia \\ E-mail: putrasantoso@sci.unand.ac.id
}

Keywords:

commercial

business, creative entrepreneurship, mammals,

unemployed youth

Kata Kunci: mamalia, remaja pengangguran, usaha komersial, wirausaha kreatif

\begin{abstract}
A marked increase in demand for white mice (Mus musclulus L., mammals) in the Indonesian market has been attributed to the price soar, while the availability of mice with a standardized quality remains very limited. Considering such condition, a business focusing on standardized farm of white mice should be actively socialized to younger people thereby elevating their enthusiasm in the entrepreneurship. This community service program aimed to provide insights as well as to train the basic skills in white mouse farming for students of the National High School Number 5 Bukittinggi. The program has been carried out for one day in the Biology Department, Andalas University with 45 participants. We deployed the lectures and hands-on practice on the aspects of white mouse farming. All participants have directly practiced various principle techniques in mice farming such as handling, sexing, mating, and raising brooders. This activity has increased the interest of the participants in such creative business. In the future, some efforts should be made to ensure the sustainability of the program by involving the participants from other schools, teachers and unemployed youth in West Sumatra.
\end{abstract}
ABSTRAK
Tingginya permintaan pasar akan mencit putih (Mus musculus L., mamalia) untuk keperluan ilmiah dan hobi di Indonesia membuat harganya melambung tinggi, sementara ketersediaan mencit dengan kualitas terstandar masih sangat terbatas. Dengan mencermati kondisi tersebut, maka usaha budidaya mencit putih terstandar merupakan peluang usaha yang sangat menjanjikan dan penting untuk disosialisasikan kepada para remaja sebagai generasi penerus bangsa. Kegiatan pengabdian kepada masyarakat ini bertujuan untuk memberikan wawasan keilmuan sekaligus melatih kemampuan dalam teknik budidaya mencit putih sebagai peluang usaha komersial yang berpotensi bagi remaja siswa SMAN 5 Bukittinggi. Kegiatan pengabdian telah dilaksanakan selama sehari di Laboratorium Riset Fisiologi Hewan Jurusan Biologi FMIPA UNAND dengan 45 orang peserta. Metode pelaksanaan berupa ceramah dan praktek langsung tentang aspek-aspek budidaya mencit putih. Selama pelaksanaan kegiatan, para peserta telah dibekali teori-teori dasar berkenaan dengan aspek biologi mencit beserta strategi pemasarannya. Selanjutnya peserta telah mempraktekkan secara langsung berbagai macam teknik dalam budidaya mencit seperti handling (memegang dan mengendalikan mencit), penentuan jenis kelamin, pengawinan, dan pemeliharaan indukan dan anakan hingga layak dijual. Kegiatan ini telah memberikan dampak berupa meningkatnya animo peserta terhadap wirausaha kreatif budidaya mencit putih. Kedepannya akan diupayakan keberlanjutan pembinaan dengan melibatkan lebih banyak pihak seperti sekolah-sekolah lainnya, guru dan remaja pengangguran di Sumatera Barat. 


\section{PENDAHULUAN}

Mencit putih (Mus musculus L.) adalah hewan pengerat dari kelompok mamalia yang banyak dikembangkan di laboratorium dan pusat peternakan hewan untuk memenuhi kebutuhan akan hewan model dalam penelitian (Jhonson, 2020; ITS, 2020). Dalam sebuah eksperimen sederhana, biasanya dibutuhkan sekurang-kurangnya 30-50 ekor mencit putih dewasa. Sedangkan untuk riset skala besar, kebutuhan akan mencit mencapai ratusan ekor (Zuzuki et al., 2015; Perrin, 2014). Selain untuk kebutuhan penelitian, permintaan akan mencit putih juga sangat tinggi dari kalangan pencita hewan melata karena mencit putih dijadikan umpan bagi hewan peliharaan terutama dari kelompok ular (Petsmart, 2020). Tingginya kebutuhan akan mencit putih baik untuk keperluan ilmiah maupun sebagai pakan bagi peternak ular di Indonesia membuat harganya melambung tinggi. Sebagai contoh, mencit putih berusia 1-2 bulan diganjar dengan harga Rp. 20.000-30.000 per ekornya (Pertanianku, 2020). Akan tetapi, ketersediaan mencit dengan kualitas terstandar untuk penelitian dan kebutuhan hobi masih sangat terbatas, terutama di luar pulau jawa. Hal ini disebabkan oleh sedikitnya jumlah peternak mencit putih profesional yang dapat memenuhi kriteria tuntutan peneliti dan penggemar hewan melata. Dengan mencermati kondisi tersebut, maka usaha budidaya mencit putih terstandar merupakan peluang usaha yang sangat menjanjikan. Berbagai peluang usaha kreatif penting untuk disosialisasikan kepada generasi muda yang memiliki motivasi untuk berwirausaha (Nurjanah, 2013).

SMAN 5 Bukittinggi didirikan pada tahun 2004 dan merupakan salah satu sekolah negeri di Kota Bukittinggi Sumatera Barat. Saat ini, terdapat 989 peserta didik yang terbagi ke dalam 30 kelas dan didukung oleh 65 orang guru (https://info.sman5bukittinggi.sch.id/). Dengan jumlah siswa yang hampir seribu orang, sekolah ini menjadi salah satu institusi pendidikan strategis untuk dijadikan mitra pembinaan generasi muda melalui berbagai kegiatan termasuk pembekalan-pembekalan yang akan memupuk motivasi dan skill kewirausahaan. Disamping itu, SMAN 5 Bukittinggi merupakan salah satu sekolah yang senantiasa proaktif dalam menjalin kerjasama dengan Jurusan Biologi FMIPA UNAND seperti dengan adanya kegiatan kunjungan laboratorium, pembekalan guru maupun partisipasi dalam perlombaan yang diselenggarakan di Jurusan Biologi FMIPA UNAND.

Kegiatan pengabdian kepada masyarakat ini bertujuan untuk memberikan wawasan keilmuan sekaligus melatih kemampuan dalam teknik budidaya mencit putih sebagai peluang usaha komersial yang berpotensi bagi remaja siswa SMA 5 Bukittinggi. Hal tersebut diharapkan dapat berdampak kepada peningkatkan animo generasi muda terhadap dunia ilmu pengetahuan dasar khususnya biologi dan kreativitasnya dalam berwirausaha sebagai modal untuk mewujudkan kemandirian ekonomi individu, keluarga, masyarakat dan bangsa.

\section{METODE}

Kegiatan pengabdian ini telah dilaksanakan selama sehari pada tanggal 3 Maret 2020 di Laboratorium Riset Fisiologi Hewan Jurusan Biologi FMIPA UNAND. Peserta kegiatan pengabdian ini adalah para siswa/i SMAN 5 Bukittinggi yang terdiri atas 45 orang yang didampingi oleh dua orang guru. Alat-alat yang digunakan dalam kegiatan pengabdian ini berupa instrumen presentasi (laptop dan LCD serta materi presentasi), kandang mencit standar, alat bedah, stereomikroskop, pinset, sarung tangan dan kamera digital. Adapun bahan-bahan yang digunakan adalah mencit putih (10 ekor), pakan mencit, serbuk gergaji, tissue gulung, detergen, sediaan embrio mencit awetan dan air mineral. 
Kegiatan pengabdian masyarakat ini dilakukan dengan metode ceramah dan praktek langsung. Metode ceramah ditujukan untuk menyampaikan materi teroritis sedangkan metode praktek langsung dilaksanakan untuk membina keahlian dasar dari peserta kegiatan (Raynolds, 2019).

\section{Persiapan Kegiatan}

Sebagai bentuk persiapan kegiatan pengabdian ini, maka dilakukan komunikasi untuk mendatangkan para peserta dari SMAN 5 Bukittinggi. Selanjutnya, sebelum hari kegiatan, dipersiapkan semua alat dan bahan yang dibutuhkan, penyiapan ruangan kegiatan, serta pengarahan terhadap asisten pembantu kegiatan yang telah berpengalaman dalam beternak mencit putih. Selain itu, materi kegiatan juga dipersiapkan dalam bentuk file power point dan video, sedangkan skenario kegiatan disusun dalam bentuk skedul acara.

\section{Penyampaian Materi Teoritis}

Materi teoritis disampaikan melalui ceramah (presentasi) sekaligus demonstrasi dengan alat-alat dan bahan peraga yang disertai dengan diskusi. Adapun materi teoritis yang disampaikan meliputi:

a. Aspek-aspek biologi mencit putih (penekanan pada aspek reproduksi),

b. Aspek keamanan dalam pemeliharaan mencit putih,

c. Peluang dan strategi komersialisasi mencit putih dengan pangsa pasar pada skala lokal dan nasional.

Sebagai bahan acuan dalam perumusan materi aspek biologi dan budidaya mencit, digunakan panduan dari beberapa referensi utama (Murdaugh et al., 2018; Institutional Animal Care and Use Committee University of Florida, 2012; Institute for Laboratory Animal Research, 2011).

\section{Kegiatan Praktek Langsung}

Dalam kegiatan praktek secara langsung, para peserta pengabdian dipandu dalam kelompok-kelompok untuk melakukan praktek secara langsung berupa:

a. Identifiksi morfologi penentuan jenis kelamin (sexing) mencit putih,

b. Penguasan teknik handling (memegang dan mengendalikan) mencit putih,

c. Teknik perawatan meliputi pemeliharaan kandang, pemberian makanan dan minuman,

d. Identifikasi embrio mencit putih dengan stereomikroskop,

e. Pembedahan mencit putih untuk identifikasi anatomi organ dalam,

f. Teknik mengawinkan mencit dan pemeliharaan anakan.

\section{Umpan Balik}

Dalam rangka mengevaluasi dampak kegiatan pelatihan kepada peserta, maka di akhir acara dilakukan sesi diskusi dimana para peserta diberi kesempatan sebanyak-banyaknya untuk memberikan pertanyaan dan umpan balik tentang aktivitas pengabdian yang telah dilakukan. Selanjutnya peserta diberikan pertanyaan-pertanyaan secara lisan satu per satu guna mengevaluasi tingkat pemahaman mereka terhadap materi pelatihan. Selain itu, keterampilan peserta dalam kegiatan praktek juga diobservasi dan diuji untuk menilai kecakapannya sebagai dampak dari kegiatan pelatihan yang diberikan. 


\section{HASIL DAN PEMBAHASAN}

Kegiatan pengabdian kepada masyarakat berupa pelatihan budidaya mencit putih dengan peserta remaja dari SMAN 5 Bukittinggi ini telah terlaksana sesuai rencana (Gambar 1 \& 2). Berdasarkan hasil evaluasi terhadap pemahaman peserta yang dilakukan di akhir pelatihan melalui metode tanya jawab secara langsung, para peserta dinilai telah memiliki pengetahuan dasar yang memadai tentang aspek-aspek biologi mencit putih meliputi siklus hidupnya, tingkah laku, reproduksi dan karakteristik perkembangannya pada berbagai fase umur. Selanjutnya, peserta juga dinilai telah memiliki pengetahuan yang baik tentang peluang usaha komersial dari budidaya mencit putih serta telah mampu melakukan kalkulasi estimasi permintaan pasar berdasarkan simulasi penjualan.
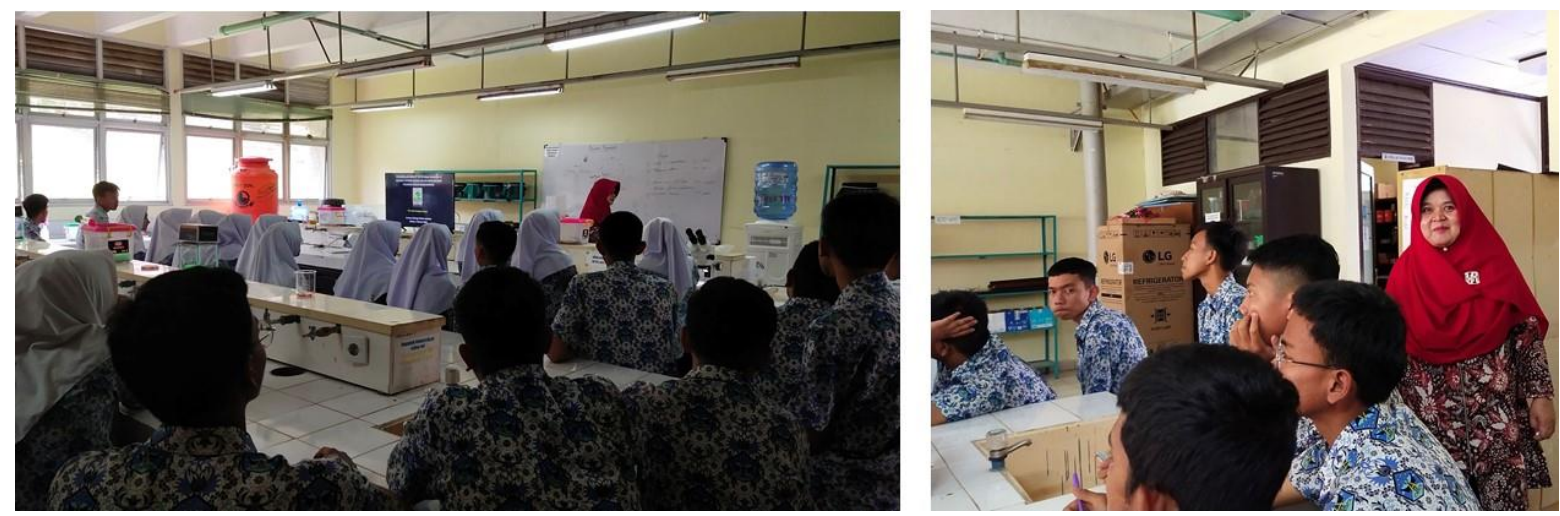

Gambar 1. Penyampaian materi tentang nilai komersial dan peluang pasar mencit putih oleh Dr. Resti Rahayu

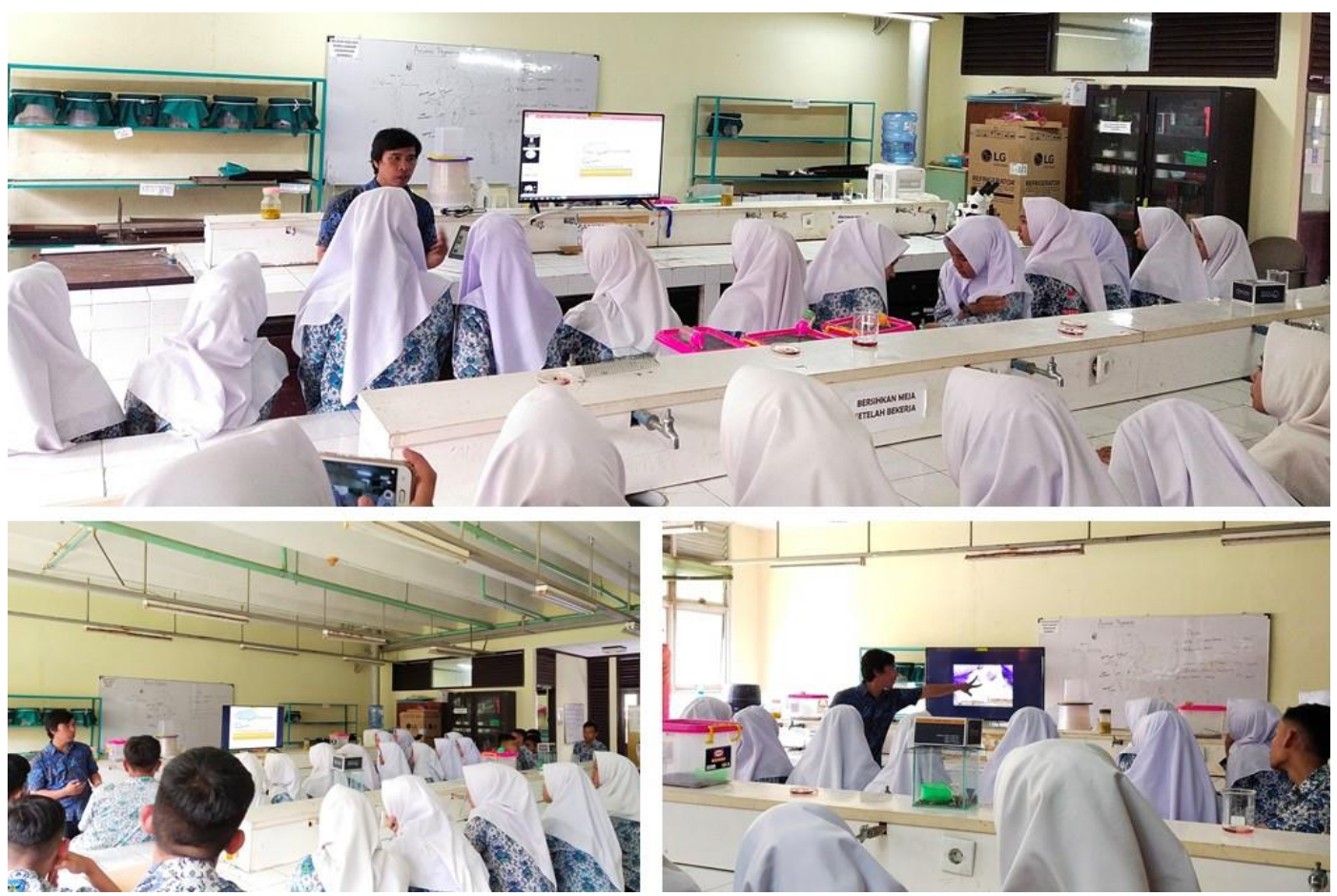

Gambar 2. Penyampaian materi tentang aspek-aspek biologi dan teknik buidaya mencit putih oleh Dr. Putra Santoso 
Selain dari peningkatan pengetahuan dasar secara teoritis, melalui pelatihan yang diberikan para peserta juga telah mampu menguasai teknik-teknik penting dalam pemeliharaan mencit putih (Gambar 3). Semua peserta telah terampil dalam melakukan handling (memegang, memindahkan dan mengendalikan mencit secara tenang) terhadap indukan mencit yang merupakan aktivitas utama dalam peternakan mencit. Selanjutnya, semua peserta juga telah terampil dalam mengidentifikasi jenis kelamin mencit secara tepat dan cepat untuk berbagai kriteria umur mencit mulai dari juvenil hingga dewasa matang yang siap untuk dikawinkan. Penentuan jenis kelamin ini menjadi aspek penting yang memang harus dikuasai oleh peternak mencit terutama untuk mengawinkan indukan mencit, mengidentifikasi calon induk yang sudah matang secara seksual dan memisahkan anakan berdasarkan jenis kelaminnya sesuai dengan permintaan pembeli nantinya (Jhonson, 2020). Selain dari keterampilan-keterampilan tersebut, para peserta pelatihan juga telah mampu melakukan teknik pembersihan bedding dengan tepat dan melakukan evaluasi terhadap kelayakan kandang dan aspek-aspek kebersihan dan kesehatan hewan sesuai dengan kriteria standar. Para peserta juga telah terampil dalam menerapkan protokol keamanan dan kesehatan dalam pemeliharaan mencit seperti penggunaan berbagai instrumen protektor, handscoon, sonde dan sterilizer.
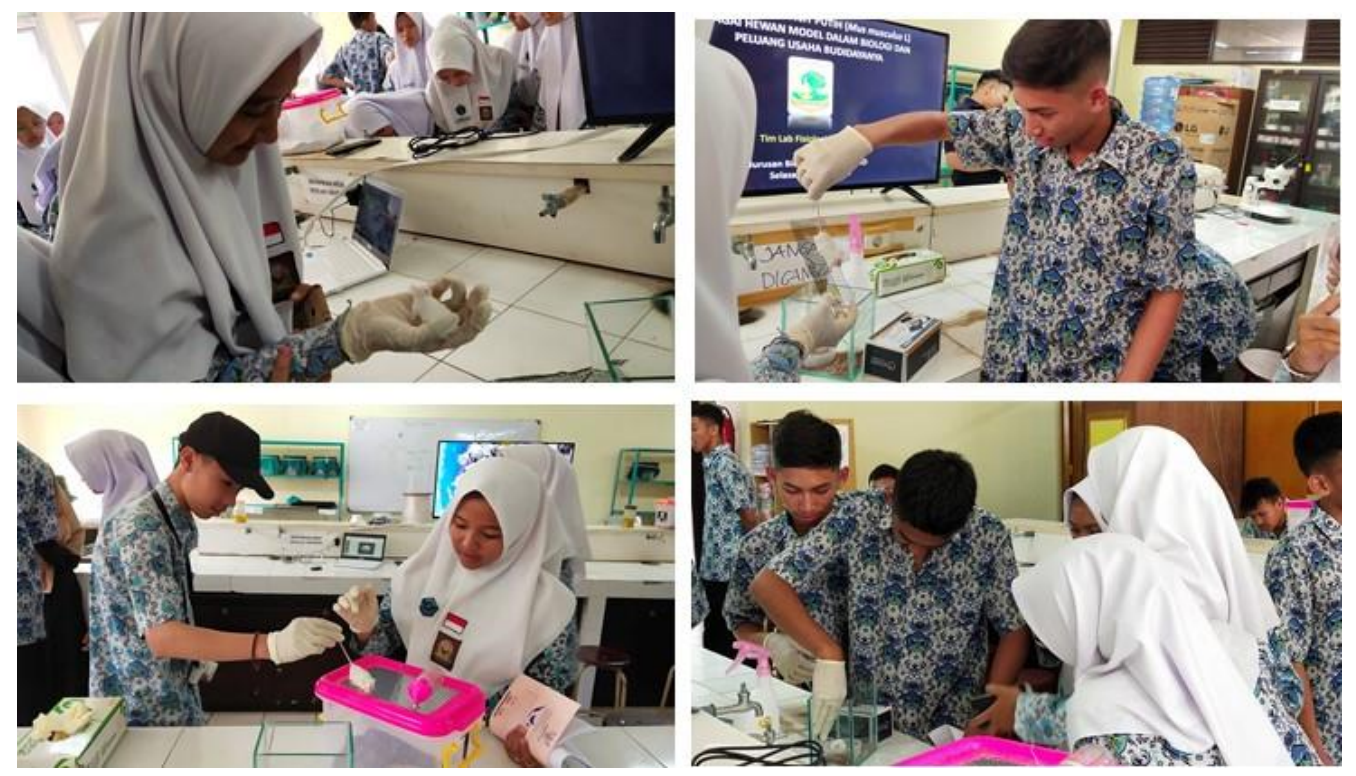

Gambar 3. Peserta berlatih melakukan teknik handling terhadap mencit putih

Melalui pelatihan ini, para peserta juga telah menguasai keterampilan dalam mengoperasikan piranti observasi embrio mencit berupa stereomikroskop (Gambar 4) dan mampu melakukan pembedahan indukan mencit guna mengidentifikasi anatominya (Gambar 5). Selanjutnya, keterampilan peserta juga meningkat dalam hal menentukan desain ruang pemeliharaan hewan berdasarkan kriteria ukuran, sirkulasi, pencahayaan dan kontrol kebisingan.

Seluruh rangkaian kegiatan pengabdian telah terlaksana dengan tanpa ada kendala yang berarti. Hanya saja, mengingat banyaknya peserta (45 orang) maka ada satu kegiatan yang tidak dapat dilakukan oleh seluruh peserta melainkan hanya perwakilan saja yaitu kegiatan pembedahan mencit untuk mengidentifikasi organ dalam terutama organ reproduksinya. Akan tetapi, untuk mengatasi kekurangan tersebut, setiap peserta telah dipandu untuk menonton perwakilannya ketika melakukan pembedahan sehingga tetap dapat memperoleh pengalaman langsung. Rekaman video pembedahan juga disediakan sehingga dapat ditonton oleh peserta di layar TV yang disediakan di ruang pelatihan. Kekurangan ini tidak tidak berpengaruh terhadap 
tingkat penguasaan keterampilan peserta dalam membedah dan mengidentifikasi mencit yang dibuktikan dengan meratanya kemampuan peserta ketika mereka diuji kecakapannya dalam melakukan kegiatan tersebut pada akhir kegiatan.
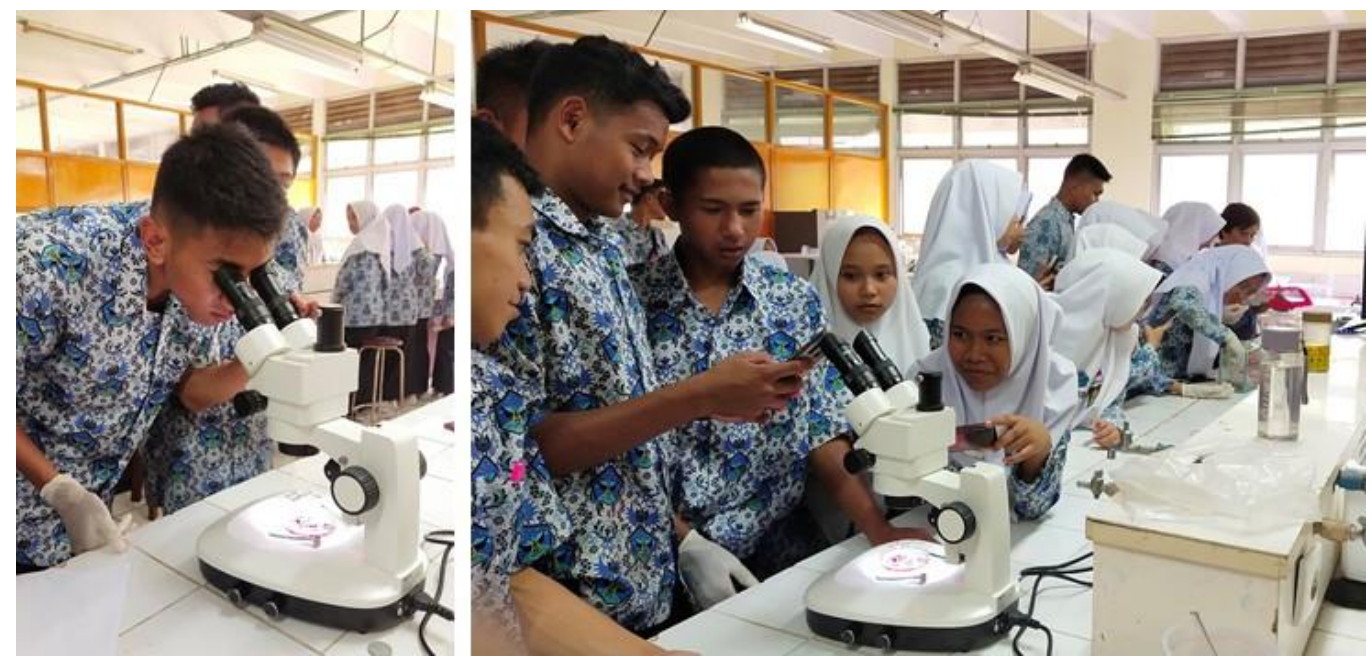

Gambar 4. Peserta melakukan pengamatan embrio mencit putih dengan stereomikroskop
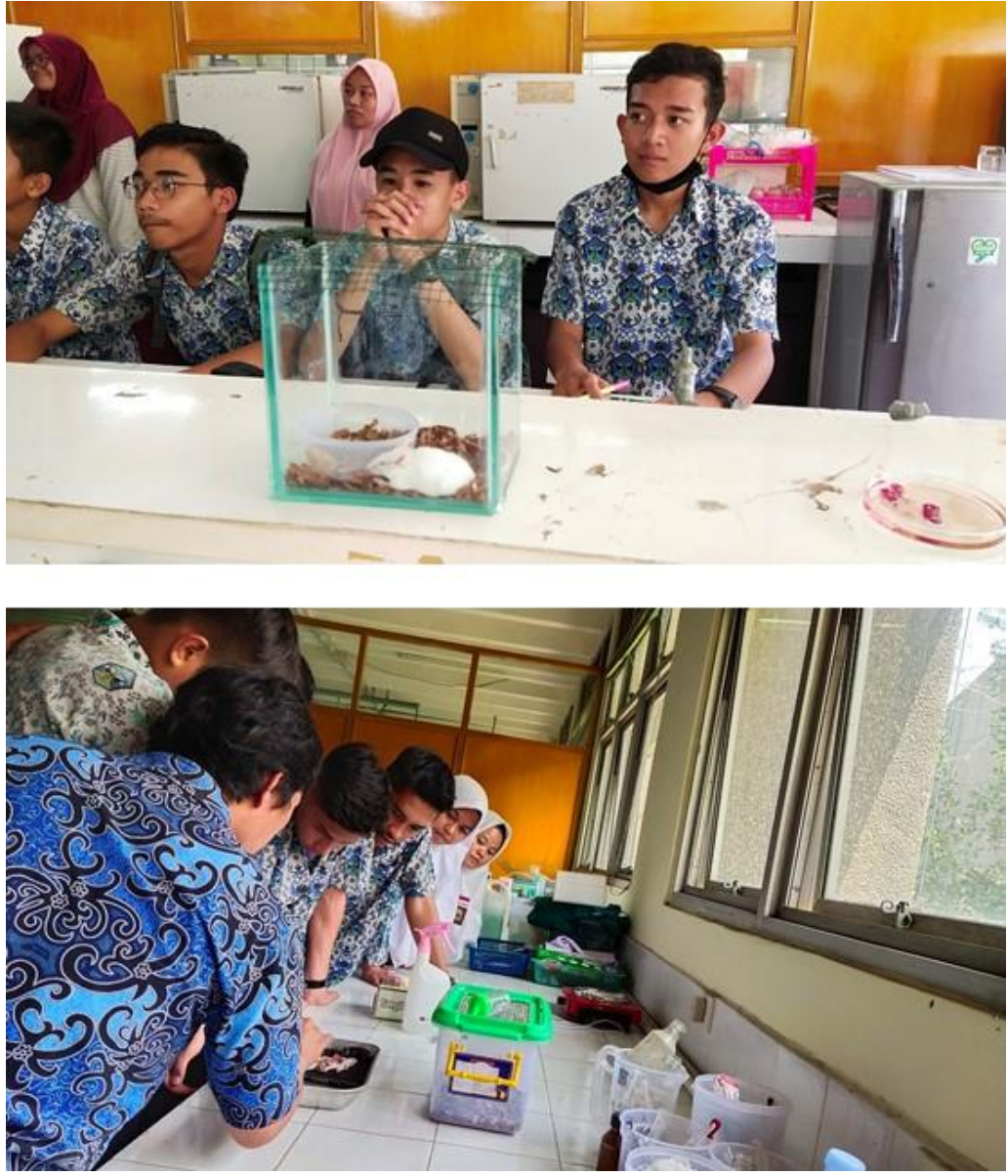

Gambar 5. Pengenalan morfologi dan anatomi mencit putih serta penentuan jenis kelaminnya 
Kegiatan pengabdian yang dikemas dalam bentuk pelatihan secara langsung kepada para remaja siswa SMA 5 Bukittinggi ini telah memberikan implikasi yang positif kepada peserta. Hal tersebut tercermin dari tingginya antusiasme peserta dalam mengikuti pelatihan baik saat penyampaian materi teoritis maupun pada sesi praktek secara langsung. Dari sesi diskusi interaktif yang dilakukan, para peserta juga memperlihatkan animo yang tinggi terhadap peluang usaha budidaya mencit putih dimasa datang. Hal ini merupakan indikator meningkatnya motivasi peserta untuk berwirausaha dan terbukanya wawasan mereka tentang seluk beluk budidaya mencit putih dari kegiatan pengabdian yang telah dilakukan. Antusiasme yang tinggi merupakan salah satu indikator penting dari keberhasilan kegiatan pembekalan keilmuan dan keterampilan (Raynolds, 2019).

Kegiatan pembekalan pengetahuan melalui praktek langsung seperti yang telah dilakukan melalui pengabdian masyarakat ini semestinya diselenggarakan secara berkesinambungan. Menurut Carter (2019), penguasaan terhadap suatu skill secara baik harus ditempuh melalui mekanisme pembelajaran berlanjut dan bertahap. Dengan mempertimbangkan hal tersebut, maka kegiatan pelatihan budidaya mencit putih kepada para remaja ini akan diupayakan untuk terus ditindaklanjuti terutama dengan menciptakan sistem kerjasama yang lebih erat dengan pihak sekolah, dalam hal ini dengan pihak SMA 5 Bukittinggi. Pada kegiatan selanjutnya, akan dipertimbangkan juga untuk melibatkan guru-guru khususnya para guru pembina kegiatan ekstrakurikuler sehingga kegiatan-kegiatan kewirausahaan yang lebih nyata kedepannya dapat dikemas secara lebih menarik dan berorientasi edukasi sains dan bisnis. Selain itu, masyarakat sasaran dari kegiatan pengabdian masyarakat ini akan diupayakan untuk kalangan yang lebih luas, misalnya dengan berbagai sekolah lainnya di SUMBAR dan juga kalangan mahasiswa maupun pengangguran yang berada di sekitar kampus UNAND.

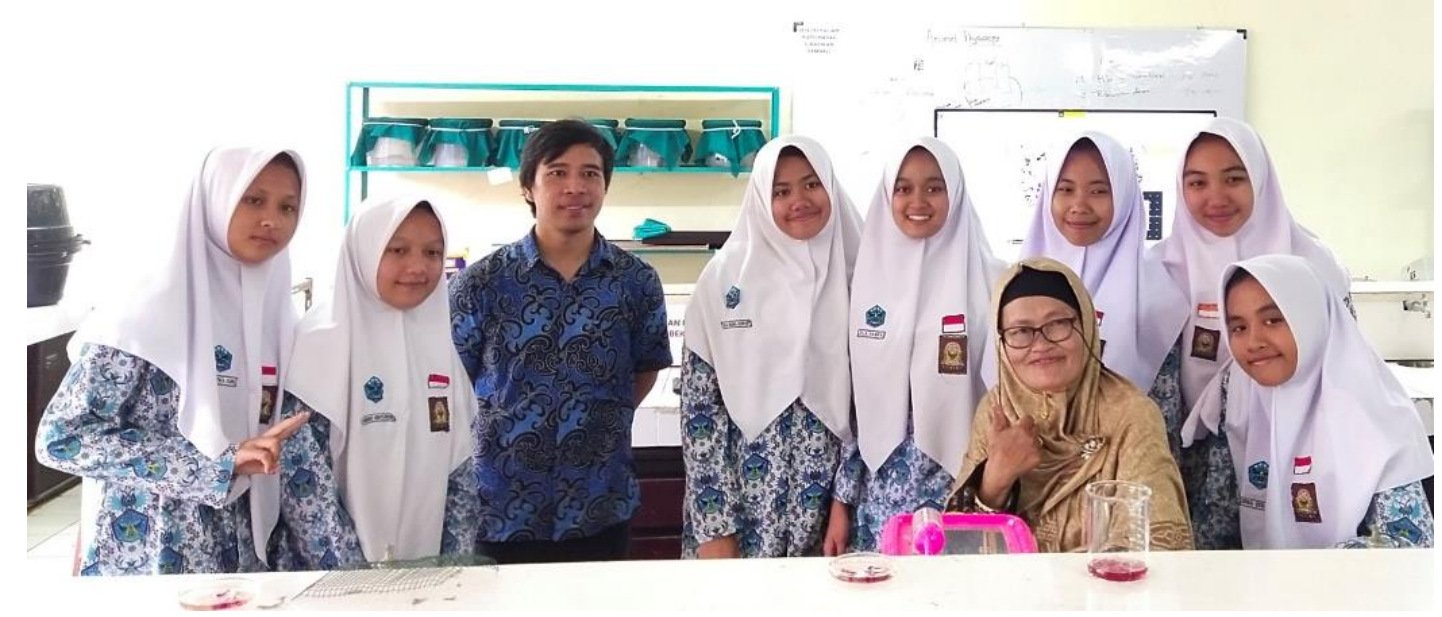

Gambar 6. Berfoto bersama dengan sebagian peserta di akhir kegiatan

\section{KESIMPULAN}

Kegiatan pengabdian kepada masyarakat ini telah dilaksanakan dengan baik dan memberikan manfaat kepada para peserta berupa peningkatan keterampilan dalam berternak mencit dan peningkatan pengetahuan aspek-aspek biologis mencit putih. Antusias para peserta kegiatan untuk berpraktek secara langsung dalam menguasai teknik dasar pemeliharaan mencit putih, aspek komersialisasinya dan pengenalan aspek biologisnya mencerminkan peningkatan motivasi dan inspirasi berwirausasha sekaligus memperdalam wawasan keilmuan generasi 
muda khususnya di bidang biologi. Untuk keberlanjutan dampak kegiatan ini, diharapkan dapat dijalin kerjasama dan pendampingan secara kontinyu dengan pihak sekolah.

\section{UCAPAN TERIMA KASIH}

Kami berterimakasih kepada Kepala Sekolah dan Guru Biologi SMAN 5 Bukittinggi atas kerjasamanya. Kami juga berterimakasih kepada Dr. Mairawita selaku Ketua Jurusan Biologi FMIPA UNAND yang telah memfasilitasi kegiatan pengabdian dan juga kepada para asisten lab Fisiologi Hewan Jurusan Biologi FMIPA UNAND atas dukungan teknisnya dalam penyelenggaraan kegiatan.

\section{DAFTAR PUSTAKA}

Carter, A. 2019. Sustained Learning: A Modern Approach for Results-Driven L\&D Professionals. The Collins james methods.Altmore International Pty. Ltd. New South Wales. Australia.

Hess, L., Axelson, R. 2019. Feeding pet snakes. https://vcahospitals.com/know-your-pet/snakesfeeding. Diakses tanggal 2 April 2020.

Institute for Laboratory Animal Research. 2011. Guide for The Care and Use of Laboratory Animals. Eighth Edition. The National Academic Press. Washington D.C. USA.

Institutional Animal Care and Use Committee University of Florida. 2012. Breeding Guidelines for Mice. The University of Florida. USA.

Jhonson, M. 2020. Laboratory Mice and Rats. LABOME. https://www.labome.com/method/Laboratory-Mice-and-Rats.html. Diakses tanggal 2 April 2020.

Murdaugh, L.B., Mendoza-Romero, H.N., Fish, E.W., Parnell, S.E. 2018. A novel method for determining sex in late term gestational mice based on the external genitalia. PLoS ONE 13(4): e0194767.

Nurjanah, S. 2013. Analisis Pengembangan Program Bisnis Industri Kreatif Penerapannya Melalui Pendidikan Tinggi. JMA. 18(2): 141-151.

Perrin, S. 2014. Preclinical research: make mouse studies work. Nature 507 (7493): 423-425.

Pertanianku. 2020. Cara ternak tikus putih atau mencit. https://www.pertanianku.com/caraternak-tikus-putih-atau-mencit/. Diakses tanggal 22 April 2020.

Petsmart. 2020. How to feed your snake. https://www.petsmart.com/learning-center/reptilecare/how-to-feed-your-snake/A0166.html. Diakses tanggal 2 April 2020.

Raynolds, J. 2019. The most effective training methods. https://hrdailyadvisor.blr.com/2019/05/22/the-most-effective-training-methods/. Diakses tanggal 1 Mei 2020. 
SMA N 5 Bukttinggi. Profil. 2020. https://info.sman5bukittinggi.sch.id/. Diakses tanggal 1 Mei 2020.

Suzuki, H., Suzuki, K., Yamada, G. 2015. Systematic analyses of murine masculinization processes based on genital sex differentiation parameters. Dev Growth Diff. 57(9):639-47.

The Integrated Taxonomic Information System (ITS). 2020. Mus musculus Linnaeus, 1758. Taxonomic Serial No.: 180366. https://www.itis.gov/servlet/SingleRpt/SingleRpt?search_topic $=T S N \&$ search_value $=180366 \# n$ ull. Diakses tanggal 24 Maret 2020. 